\title{
Harmonisasi Collecting Societies Menuju Sistem Pemungutan Royalti Yang Transparan
}

\author{
Oleh : \\ SHABHI MAHMASHANI
}

\begin{abstract}
There are a lot of problems in the Indonesian royalty system. One of the problems is the overlapping collecting societies authorities. Finding the way to harmonize several collecting societies whose overlapping authority is the goal of this article. And based on the writer research, there are two ways to harmonize the overlapping collecting societies. First is centralizing collecting societies's authority in one institution. And second is distributing the collecting societies's authority. Goverment as the highest instituion in the state has to support by making a regulation for the collecting sociceties.
\end{abstract}

